Reprinted from "The Proceedings of the Indian Academy of Sciences",

Vol. XLVI, No. 4. Sec. B, 1957

\title{
SOME OBSERVATIONS ON THE REPRODUCTION OF THE MILKFISH CHANOS CHANOS (FORSKÅL)
}

\author{
BY P. R. S. TAMPI \\ (Central Marine Fisheries Research Station, Mandapam) \\ Received April 20, 1957 \\ - (Communicated by Dr. N. K. Panikkar, F.A.Sc.)
}

\section{INTRODUCTION}

SEVERAL aspects of reproduction of the milkfish are still baffling and the progressive reproductive phases of the gonads and the spawning cycle in the fish are not properly understood. The validity of a statement by Chaudhuri (1916) that the ripe roe of Chanos is dried, smoked and sold by fishermen around the Chilka Lake which conveys an impression of common occurrence of the breeders was inquired into and it is understood that the fish are now rare in these places. Apart from the occasional notes on the well developed roe and the number of eggs produced by the fish, by Sunier (1922) and Adams et al. (1932), the only critical approach to the problem has been by Bunag (1951) who made an effort to ascertain the spawning habits of the fish on the basis of ova diameter measurements of the developing ovarian eggs. This extreme paucity of literature is largely owing to the difficulty in obtaining sufficient material for study, particularly of the more advanced stages in the development of the gonads. For the same reason, although rarely mature gonads have been seen in a few fish caught from the sea, it is rather hard to build up a connected picture of the developing reproductive organs; the result has been that no reliable account of the frequency of spawning or size at maturity are available. The condition of gonads in the majority of specimens caught from the sea in the fishing nets and in those obtained from fish ponds is such that even sex determination to the unaided eye is difficult.

In order to have a statistically sound answer to the various problems, collection of a large amount of material involving a considerable lapse of time will be necessary. But meanwhile, some observations based on material obtained during the last few years are presented here which might partly fill the existing lacuna and will eventually lead to a fuller understanding of the various aspects in the biology of the fish.

\section{METHODS}

The account is based mainly on Chanos collected off and on along the coast around Mandapam. The fish were dissected, the gonads taken out 
and portions of them were fixed in Bouin's fluid for histological studies and the rest preserved in 5 per cent. formalin. Paraffin sections were stained in iron hæmatoxylin and counterstained with eosin. Mallory's collagen stain was also used. The determination of the number of ova in the gravid females was done in the fresh condition using the method of counting the eggs in a portion of known weight and then calculating the total number from the total weight of the ovaries. The ova diameter measurements were made in sections, more or less according to the procedure employed by De Jong (1939) and later workers on similar studies. In drawing the size frequency curves the diameter of about five hundred ova from each pair of ovaries were measured throughout at a magnification of $10 \times 10$ and grouped in 2 ocular micrometer division intervals when each division represented 14 micra. Histological descriptions of the ovary and the intraovarian eggs at various stages are broadly on the lines given by Franz (1908) and that of the testes after Craig-Bennet (1931). However, since cytological details are not of prime importance in this account several details have been omitted.

While referring to the length of the fish, the total length from the tip of snout to end of the longest lobe of the caudal fin is always given.

\section{THE GONADS}

The external characters of the fish do not at any time permit us to distinguish the sex. In fish usually under about $500 \mathrm{~mm}$. in total length the gonads themselves are hardly recognisable except as thin streaks of greyish-white, cord-like tissue loosely attached to the peritoneal wall dorsal to the alimentary canal and ventrolateral to the air-bladder. They extend almost to the whole length of the cœlomic cavity and may often be mistaken for a blood vessel. The differentiation into the ovary or the testis at this stage is difficult even under a microscope. Sections from the various regions also reveal only some undifferentiated mass of cells covered over by a coat of connective tissue and two blood vessels associated with it.

The Testis.-The descriptions are confined to two important stages, (i) the very early stage when the gonad becomes just recognisable histologically into the testis so that sex determination is possible in early juveniles and (ii) the very advanced or mature condition where the sperms are fully formed just prior to spawning. Descriptions of either of these are lacking in literature. The author has not come across intermediate stages in the maturation of the testis or the spent testis and thus it has not been possible to assign any different developmental stages of the testis as has been followed in the case of the ovary. 
The differentiation of the undeveloped gonad into the testis is possible by studying sections and even this is apparent only in juveniles longer than about $500 \mathrm{~mm}$. The testis remains as a thin cord of tissue having a maximum width of $2.5 \mathrm{~mm}$. with a slightly pinkish-grey coloration even in fish up to about $900 \mathrm{~mm}$. length. The thin mesorchium with which the testis is attached along its length to the peritoneal lining has scattered melanophores. Transverse sections of the testis at various levels reveal that the testicular material at this stage is confined to the anterior half of the elongated organ and posteriorly it is composed only of connective tissue and blood vessels.

Figure 1, Plate XVII shows a part of the testis of a fish of $690 \mathrm{~mm}$. in a transverse section. The testis is provided with a fibrous connective tissue capsule covered by a mesothelial lining forming the tunica $(t u)$ which is thicker toward the inner lateral side where a main artery and a vein are present. The attachment of the mesorchium is towards the inner dorsal margin. The mass of apparently undifferentiated cells of the testis is seen to be clumped together into small groups or lobules ( $l$.) and are clearer along the peripheral regions ( $c f$. Matthews, 1938). The cells are the resting sperm cells or the spermatogonia (spg.). The majority of the cells are large and possess clearly stained, round nuclei with an average diameter of 4 micra and small masses of darkly staining chromatin and one or two plasmosomes (Fig. 2, Pl. XVII). The cytoplasm is lightly stained and the cell-walls are somewhat clearly defined. In the testis of a fish of $830 \mathrm{~mm}$. a few polygonal cells with small intensely staining round nuclei of only 2 micra in diameter and definitely granular cytoplasm may be seen. No mitotic figures or dividing spermatogonia have been found in any section of the testes taken from fish of varying lengths up to $830 \mathrm{~mm}$. This might indicate that active spermatogenesis takes place only at later stages which are not represented in the present set of material. Further cytological details or the significance of the various types of cells and other descriptions in the progressive spermatogenesis are definitely outside the scope of this account.

The only other stage in the development of the testis obtained is the fairly mature testis which bears very little external resemblance to the stage described above. In this condition each testis appears as a rosy-white, elongated structure, broadest at about the middle and tapering at either ends (Fig. 3, Pl. XVII). The size of the testis varies in individual fish. In two specimens of 1,080 and $1,140 \mathrm{~mm}$. length the testes measured $325 \times 55 \mathrm{~mm}$. and $280 \times 43 \mathrm{~mm}$. respectively excluding the vas deferens which itself is nearly half the length of the testis. The vas deferens is a continuation of the large spermatic duct and the vas deferens from each testis unite in the middle to 
open to the outside by a common opening situated between the anus and the urinary aperture.

In this nearly mature condition the testis is heavy, somewhat soft to the touch and does not yield any milt under moderate pressure. Both the testes in a fish are equally developed. The general disposition of the testes (tes.) in the cœlomic cavity is schematically represented in the right half of TextFig. 1. The mesorchium (mor.) which is a thin, tough, translucent membrane devoid of much pigmentation is attached to the testis along its inner lateral side a little below the dorsal margin. On the same side are seen the spermatic
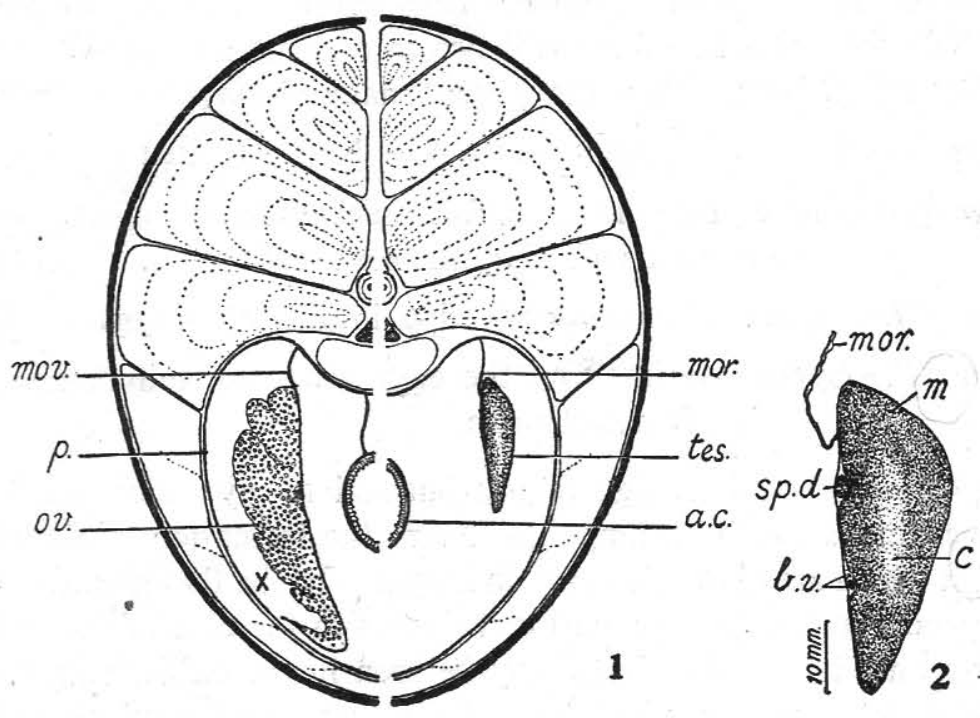

Text-Figs. 1-2. Fig. 1. Schematic drawing of a transverse section of Chanos showing the gonads in situ. The right half represents that of the male and the left that of the female.

Fig. 2. Transverse section of a mature testis.

duct (sp.d.) a large artery and a vein lying superficially along the length of the organ (Text-Fig. 2). Transverse sections of mature testis when stained with iron hæmatoxylin will reveal an outer intensely stained cortical region $(c$.$) and a relatively narrow, lightly staining central medullary zone (m$.). The covering of the testis is composed of a thin connective tissue membrane while the testis itself is made up of a mass of spermatic tubules which open into the common collecting duct. These spermatic tubules are outlined by connective tissue fibres and blood capillaries. Fully formed spermatozoa (Fig. 4, Pl. XVII, $s p$.) present inside the tubules are densely accumulated along the peripheral regions of the testis which, when stained, give the apparent differentiation into the cortical and medullary regions. Each spermatozoa 
has a tiny head, shaped almost like an inverted cup, and a long tail. In this advanced testis, besides the sperms various stages in the maturation of the spermatocytes $(s p c$.) are also seen. The question of the presence of interstitial cells in the testis has not been gone into although it might prove significant in a detailed study of the cyclic changes in the testis.

The ovary.-The ovaries in the fish since they become definitely recognisable may be arbitrarily classified into four broad groups depending on the degree of development. However, it is to be made clear that this grouping does not in anyway correspond to the international standards in the classification of the maturing ovary, but has been adopted here in this preliminary account only for the sake of convenience in description and will necessarily have to be revised later. Thus the present material may be classified as:-

Stage I.-The earliest ovary which can be recognised histologically.

Stage II.-Where there is a uniform development of ova within the ovary and including all immature stages.

Stage III.-Enlarged ovaries with ripe intraovarian eggs.

Stage IV.-Spent ovaries after the eggs are shed and sometimes with re-forming early ova.

Stage I.-The obvious sign of ovarian activity by which the female reproductive organs can be distinguished, viz., the formation of the oocytes is seen in fish which are about $500 \mathrm{~mm}$. in length. In the thin gonad the oocytes are first produced nearer the anterior region as in the case of the testis, while posteriorly only connective tissue may be seen in the earlier stages. Fig. 5, Pl. XVIII shows a section taken from the anterior region of an early ovary where a few developing ova (ocy.) can be clearly recognised by their large size, almost ovoidal shape and finely granular cytoplasm which takes a deep stain with iron hæmatoxylin or acid fuchsin. The nucleus is also large and round with a prominent nucleolus. Comparatively smaller cells measuring on an average 7 micra are the oogonial cells (og.). The cytoplasm of these cells is clearer and the nuclei of these are also round and have scattered chromatin.

Stage II.-With the active development of the ova external morphological changes of the ovary gradually become apparent. There is slight enlargement of the ovary towards the anterior two-thirds where a pale pinkish colouration develops while the posterior region still remains attenuated. The ovarian tissue at this time is almost confined to the anterior major portion of the organ which becomes distinct. The mesovarium with which the ovary is attached to the dorsal peritoneum and also the formation of thin ovigerous lamellæ (ov.l.) are visible at this stage. The general shape of the organ may 
vary according to the extent of development of the ovigerous lamellæ, but in this Stage II is included all immature stages in the development of the ovary. Thus the shape may vary from a thin, flat, lanceolate structure as in TextFig. $3 \mathrm{~A}$ to a broader and more succulent organ as shown in Text-Fig. 3 B. The colour also varies correspondingly from a light pink to bright pink or pale orange-yellow depending on the maturation of the ova within them. In a fish of $990 \mathrm{~mm}$. length the ovaries measured $160 \times 27 \mathrm{~mm}$. The ventral margin of the ovaries now develop a fold $(f$.) as is shown in the transverse section in Text-Fig. $3 \mathrm{~B}$.

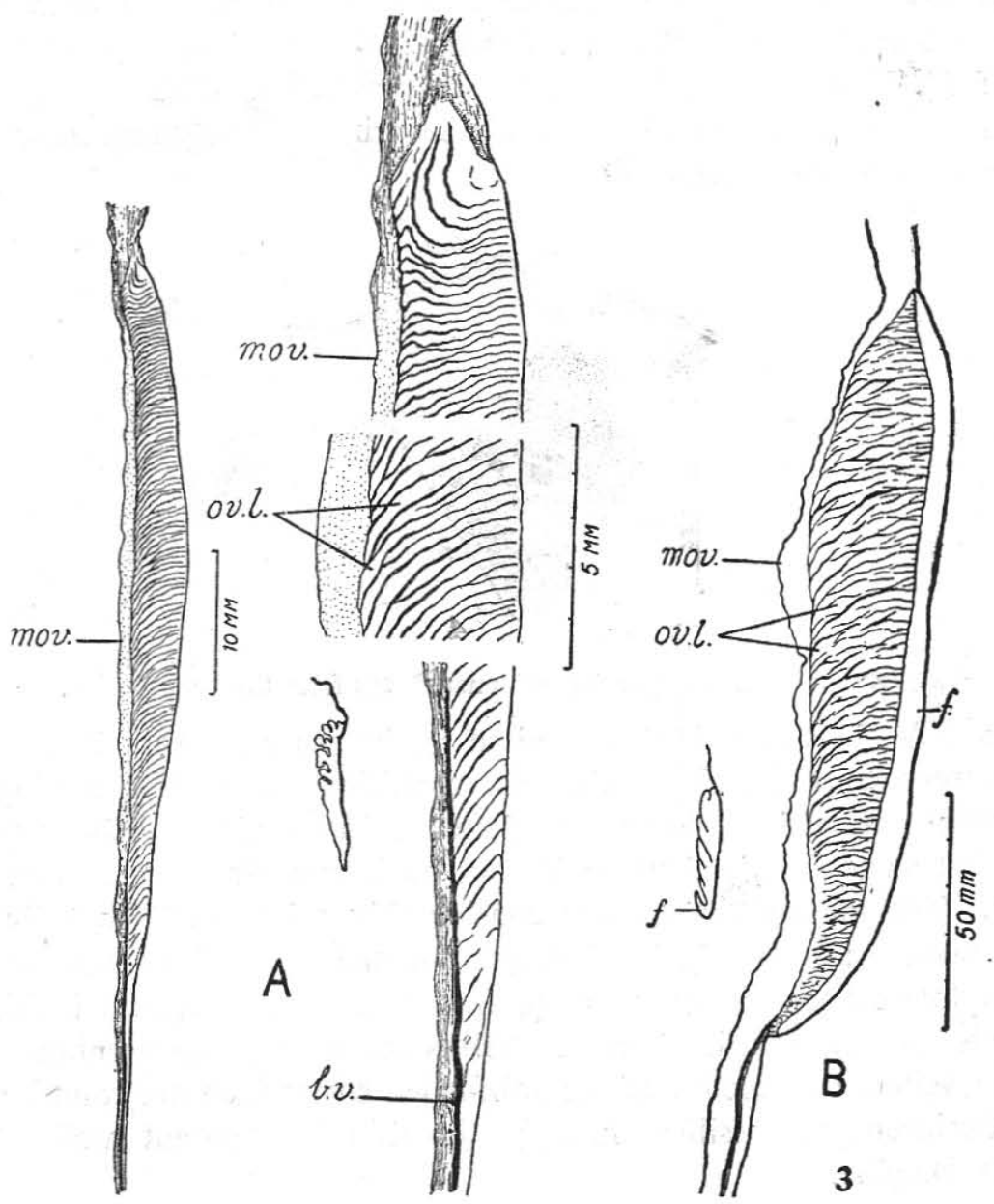

TeXt-Fig. 3. Immature ovaries of stage II. A. Entire ovary of a $502 \mathrm{~mm}$. fish; enlarged drawing of the anterior, middle and posterior regions and also a transverse section showing the formation of the early ovigerous lamellæ. B. Entire ovary of a fish of $990 \mathrm{~mm}$., a transverse section is also given alongside which shows the ventral marginal fold of the ovary. 
Figures 5 and 6, Pl. XVIII show sections of ovaries of two fish $670 \mathrm{~mm}$. and $990 \mathrm{~mm}$. respectively. The difference in the state of maturity may be clear from these figures; Fig. 5 shows a very early condition while Fig. 6 exhibits a more advanced stage. The distinctive feature of the more developed ova, besides their larger size, are a granular cytoplasm which stains less intensely with acidophilic dyes, a large round nucleus of about 70 micra diameter within which are present a number of deeply staining nucleoli mostly arranged along the margin and a fine chromatin network in the middle (TextFig. 4). The outer membrane also becomes distinct. The ova of the less advanced stages are considerably smaller and have the same cytological nature as those of Stage I. In the $990 \mathrm{~mm}$. fish the majority of the eggs have a diameter of 28-56 micra which represent the immature stock. Larger eggs varying in size up to about 140 micra are seen in this ovary and these larger ones are the maturing eggs.

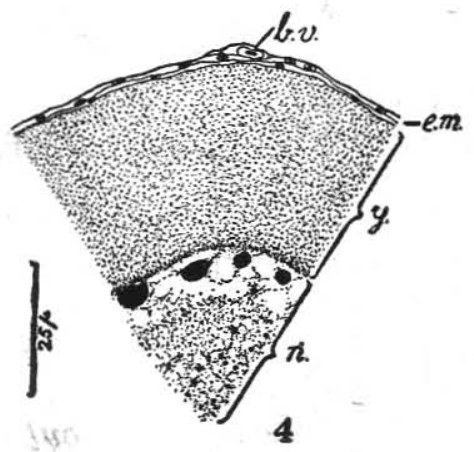

TeXT-Fig. 4. Section in part of an immature egg from the $990 \mathrm{~mm}$. fish.

Stage III.-This stage is characterised by the nearly mature intraovarian eggs and represents the most advanced condition of ovarian development in the present collection. There, no doubt, exists a wide gap between this and the last stage described under II, but no intermediate stages have been obtained. The mature ovaries are considerably enlarged. The belly of a fish with such ovaries is highly distended and the pressure exerted by these on the abdominal wall is so enormous that as soon as a ventral incision of the body is made the ovaries force themselves out through the opening. They are bright yellow on account of the yolk-laden eggs which are round, somewhat translucent and visible through the thin transparent wall of the ovigerous lamellæ.

Text-Fig. 1 is here recalled, the left half of which shows in a diagrammatic way the disposition of the ovary within the cœlomic cavity as seen in a transverse section of the body of the fish. In the normal swimming position 
of the fish the ovaries are suspended from the dorsal wall of the cœlome by the mesovarium which is continued as the ovarian wall and to which the ovigerous lamellæ are attached. Text-Fig. 5 shows the two sides of an ovary, the outer lamellar and the inner lateral side respectively. The ovigerous lamellæ are exposed and face the cœlomic wall, closely arranged in transverse

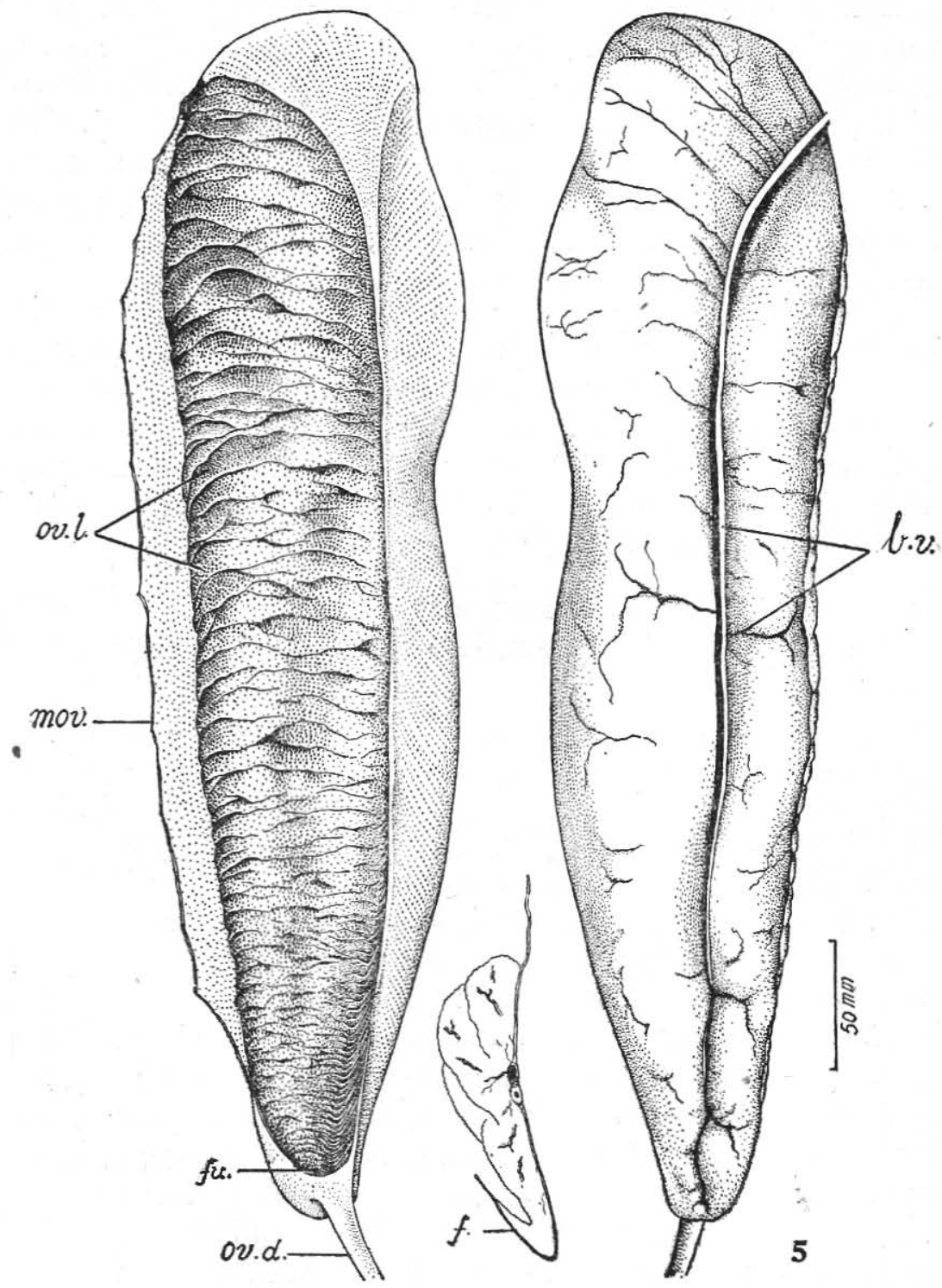

Text-Fig. 5. The two sides of a nearly mature ovary from a fish of $1,250 \mathrm{~mm}$. and also a transverse section showing arrangement of the ovigerous lamellæ. 
rows. Thus the ovary is of the gymnovarian type unlike in many other teleosts where the lamellæ are completely enclosed in a hollow sac and the type of ovary is called cystovarian. Each ovary in transverse section is seen to be slightly folded along the ventral side thereby cutting off a longitudinal space of the cœlomic cavity (marked X in Text-Fig. 1) into which the-ovigerous lamellæ project. Towards the tapering posterior end of each ovary the ovarian wall together with the mesovarium forms a funnel-shaped structure serving as an 'oviducal funnel' ( $f u$. $)$ which leads to a short oviduct. The oviduct is about one-and-a-half inches long and each oviduct from either side unites in the middle and opens to the outside by a single genital aperture in front of the anus. The eggs are liberated into the cœlomic space adjacent to the ovary and are collected near the oviducal funnel from where they are conducted along the oviducts to the outside.

The two ovaries in a fish are more or less symmetrically developed (Fig. 8, Plate XVIII)-although the shape and the size of the two may show some variation among individual fish. The Table on page 265 gives the measurements of the ovaries in three fish. The development of the ova within each ovary is uniform throughout and for ova diameter measurements samples were taken only from the middle region.

The maximum size of the mature eggs in these three pairs of ovaries varies from 728 to 756 micra (corresponding to 52 and 54 ocular micrometer units) in preserved material whereas when separated and measured in the fresh condition in normal saline their diameter varied from 800 to nearly 880 micra. Some amount of shrinkage during preservation as well as slight enlargement in saline solution may occur and thus the average size of the intraovarian eggs may be said to be of the order of 800 micra $(0.8 \mathrm{~mm}$.). Delsman (1929) gives $0.7 \mathrm{~mm}$. as the average diameter of a mature intraovarian egg. The eggs when fresh are nearly translucent and become opaque on preservation. No oil globule is present but have finely divided yolk. In sections (Figs. 9 and 10, Pl. XIX; Text-Fig. 6) the yolk region which extends to about 280 micra all round the nucleus is seen to be composed of tiny spherules (y.g.) of 2-3 micra. The outermost layer of yolk granules take a comparatively deeper stain with acidophilic dyes and is often seen prominently just beneath the egg membranes. As maturation of the egg advances, this peripheral layer becomes less acidophilic and stains only like the rest of the yolk. The various layers like the theca externa, theca interna, granulosa and zona pellucida which together constitute the egg membrane covering the egg (e.m.) measure on an average 7 micra in thickness. The nucleus (n.) is about 140 micra and does not show a definite membrane. A number of nucleoli 
arranged nearer the margin and scattered chromatin granules in the centre are also visible.
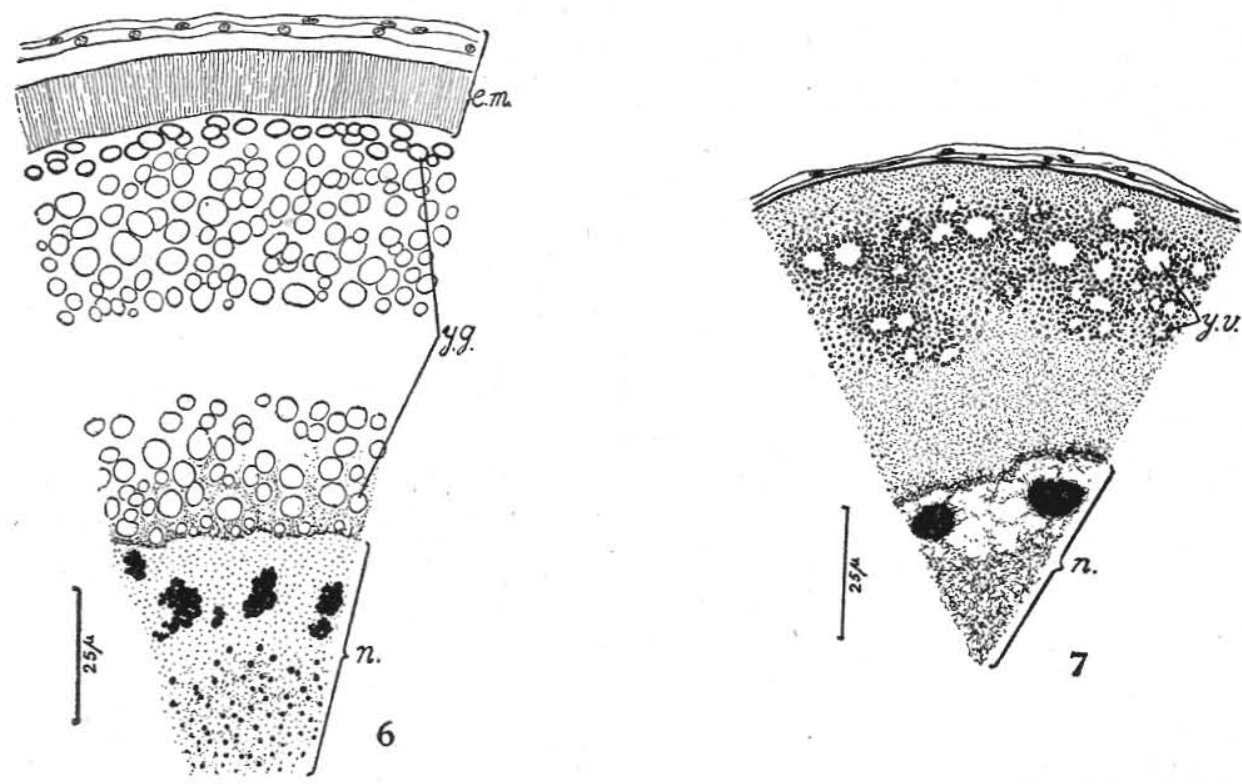

Text-Figs. 6 \& 7. Fig. 6 . Part of a section of a nearly mature egg. Only about one. third of the yolk region is represented in the drawing. FIG. 7. Similar section of a reforming egg from a spent ovary of fish of $1,240 \mathrm{~mm}$. long.

Stage IV.-The considerably reduced size of the ovaries with the lamellæ shrunken and falling apart, a pale reddish-grey colouration and flaccid nature, all very much unlike the mature ovaries, are almost ready indications of their spent condition. Fig. 11, P1. XIX shows the section of a spent ovary. The majority of the ova shows a size range of 56-84 micra representing the primitive stock of eggs. A very small number of larger opaque eggs, which are not shown in the photograph, are also present which are those left over after the spawning and are in a state of reabsorption. In the case of fish of $1,260 \mathrm{~mm}$. with similar spent ovaries, a number of eggs with an average diameter of 200 micra are noticed. Besides their larger size from the immature eggs these eggs show the formation of yolk vesicles (y.v.) and small yolk granules towards the peripheral zone indicating thereby a state of reformation (Text-Fig. 7).

The histological nature of the spent ovary, particularly of the $1,260 \mathrm{~mm}$. fish, deserves special mention. Numerous small, orange-yellow round bodies are noticed on the surface of the ovaries. In sections these are found scattered throughout among the immature eggs and appear like disintegrating follicles (Fig. 12, P1. XIX, c.l.). A closer study reveals that these are composed 
of cells showing large vacuoles and round nuclei with scanty chromatin material. Similar structures, but in much fewer numbers, are also noticed in sections of the spent ovary of a $1,240 \mathrm{~mm}$. fish but not seen in another spent fish of $1,203 \mathrm{~mm}$. The histological nature of these peculiar bodies suggests a close resemblance to some of the stages in the formation of the "corpus luteum" described in Rhodeus by Bretschnieder and Duvyené de Wit (1947) and in Fundulus by Matthews (1938) and may be comparable to similar structures now described in other teleosts and a more detailed study of their histophysiology seems to be necessary in view of their probable hormonal function as reviewed by Hoar (1951).

\section{EgG PRoduction}

The approximate number of mature eggs in the ovaries of the gravid females is roughly from 2 million to about 5 million as may be seen from the table given below. Sunier (1922) estimated the number of eggs in a fish to be $57,00,000$ which slightly exceeds the maximum obtained here, while Adams et al. (1932) found over 3 million eggs in a fish. No other figures seem to be available, but these in general seem to be in agreement with what has been observed in most other teleosts, viz., that the total number of eggs produced by each fish is nearly proportional to its length.

\section{SiZe at Maturity}

Although the material on hand is insufficient for any conclusion, indications are that in the females the ovary starts active development with the formation of the early oocytes when the fish is about $500 \mathrm{~mm}$. in length whereas in the males the spermatocytes begin to appear in the testis only after the fish reaches a size of more than $900 \mathrm{~mm}$. Similarly measurements of males and females of about the corresponding stage of maturity show that the former are smaller than the latter thereby indicating that maturation of the testis proceeds at a faster rate than the ovary.

Since histological study of the ovaries of the three gravid females does not reveal the possibility of the fish having spawned previously it is assumed that these fish have been spawning for the first time. Thus it may be said that the first spawning takes place when the fish is about $1,100 \mathrm{~mm}$. long (ca. $11.0 \mathrm{~kg}$. in weight).

The probable age at which sexual maturity sets in is not known and an attempt was male by the author to estimate the approximate age of the mature fish. A study of the scales from different regions of the body, otoliths and other ossified centres was made and some very tentative conclusions have been reached. According to these preliminary observations, the author has reasons to suspect that the age of the female fish at first maturity is roughly 
Table giving ovary dimensions and number of eggs

\section{Ovary}

\begin{tabular}{|c|c|c|c|c|c|c|c|c|}
\hline & & & & & & & & \\
\hline No. & Date & $\begin{array}{l}\text { Length of } \\
\text { fish (mm.) }\end{array}$ & $\begin{array}{l}\text { Weight of } \\
\text { fish (Kg.) }\end{array}$ & $\begin{array}{l}\text { Length } \\
(\mathrm{mm} .)^{*}\end{array}$ & $\begin{array}{l}\text { Width } \\
\text { (mm.) }\end{array}$ & $\begin{array}{l}\text { Thickness } \\
\text { (mm.)* }\end{array}$ & $\begin{array}{l}\text { Weight } \\
\text { (gm.) }\end{array}$ & $\begin{array}{l}\text { Number of } \\
\text { eggs in the } \\
\text { two ovaries }\end{array}$ \\
\hline 1 & $5-3-1954$ & 1,105 & $11 \cdot 79$ & $\begin{array}{l}342 \\
355\end{array}$ & $\begin{array}{r}110 \\
98\end{array}$ & $\begin{array}{l}28 \\
23\end{array}$ & 824 & $21,18,000$ \\
\hline 2 & $7-3-1954$ & 1,210 & $11 \cdot 80$ & $\begin{array}{l}408 \\
425\end{array}$ & $\begin{array}{r}110 \\
85\end{array}$ & $\begin{array}{l}25 \\
25\end{array}$ & 1,010 & $34,33,000$ \\
\hline 3 & 7- 3-1954 & 1,250 & $13 \cdot 60$ & $\begin{array}{l}435 \\
438\end{array}$ & $\begin{array}{l}108 \\
120\end{array}$ & $\begin{array}{l}27 \\
30\end{array}$ & 1,405 & $48,96,000$ \\
\hline $4:$ & $16-10-1951$ & 1,240 & $12 \cdot 24$ & $\begin{array}{l}255 \\
225\end{array}$ & $\begin{array}{l}43 \\
36\end{array}$ & $\begin{array}{l}10 \\
10\end{array}$ & . & \\
\hline 5 & $8-2-1954$ & 1,203 & $15 \cdot 51$ & $\begin{array}{l}275 \\
280\end{array}$ & $\begin{array}{l}52 \\
57\end{array}$ & $\begin{array}{l}11 \\
14\end{array}$ & .. & Spent \\
\hline 6 & $24-2-1954$ & 1,260 & $14 \cdot 60$ & $\begin{array}{l}302 \\
293\end{array}$ & $\begin{array}{l}53 \\
68\end{array}$ & $\begin{array}{l}15 \\
15\end{array}$ & .. & \\
\hline $7 \dagger$ & .. & 1,120 & $11 \cdot 90$ & .. & .. & .. & 1,304 & $57,00,000$ \\
\hline $8 \ddagger$ & . & . & .. & .. & .. & . & .. & $30,00,000$ \\
\hline
\end{tabular}

* After preservation in formalin. Of the two sets of figures given the first one refers to the ovary of the right side of the fish and the other left.

$\dagger$ Data from Sunier (1922).

$\ddagger$ Recorded by Adams et al. (1932).

between 4 and 5 years (at about a length of $1,100 \mathrm{~mm}$.). Similarly the females attain the early Stage II mentioned in this account when it is about 2 years old ( $c a .600 \mathrm{~mm}$. long) and takes another year to reach the late Stage II when the fish is about $900 \mathrm{~mm}$. long. ${ }^{1}$

\section{Type of Spawning and Spawning Period}

A study of the ova diameter measurements of even these limited number of ovaries at different stages of development is of some help in interpreting

${ }^{1}$ Further collection of data relating to the question of age determination in the fish is in progress and it is hoped to publish a fuller account in due course. 
the frequency of spawning of the fish. In the ova size frequency curve (TextFig. 8) of a fish of $990 \mathrm{~mm}$. length with the ovaries in a very early stage of maturation, only a single group comprising the immature eggs ranging in diameter up to about 140 micra is seen. Text-Fig. 9 gives the ova size frequencies in the ovaries of the three gravid females. These curves in general resemble that for the clupeoid fish Chirocentrus dorab whose spawning period has been discussed by Prabhu (1956). In all the curves there is a preponderance of primitive eggs whose diameter varies up to about 224 micra and with a single peak at a frequency of 56-84 micra (corresponding to 4-6 oc. mic. units in the graph). After this the curves show a gap until another distinct group of larger eggs occurs whose diameter varies between 504 and 756 micra (corresponding to 36 and 54 mic. units). The slight differences in the peak level in individual curves only indicate the state of maturity of these eggs in the different fish depending on the actual time at which these are to

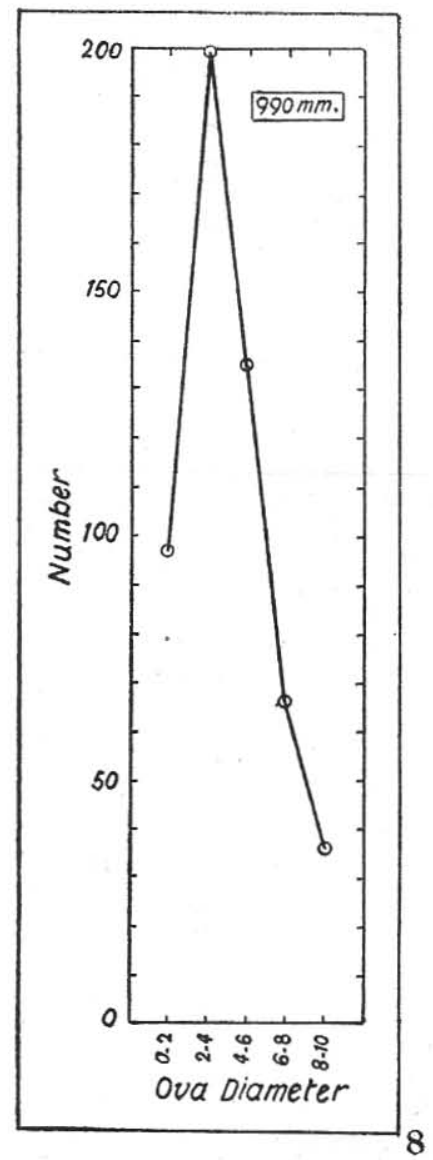

Text-Fịg. 8, OQva dịameterer frequencies in the ovary of Chanos of $990 \mathrm{~mm}$. lengțh. 
be shed in each case. Thus this group represents those getting mature to be liberated during the spawning season. The absence of multiple modal curves and the presence of only two widely separated groups of eggs, viz., the immature and mature ones, indicate that the fish has only one spawning season in a year. At the same time the indistinct minor modes within the group

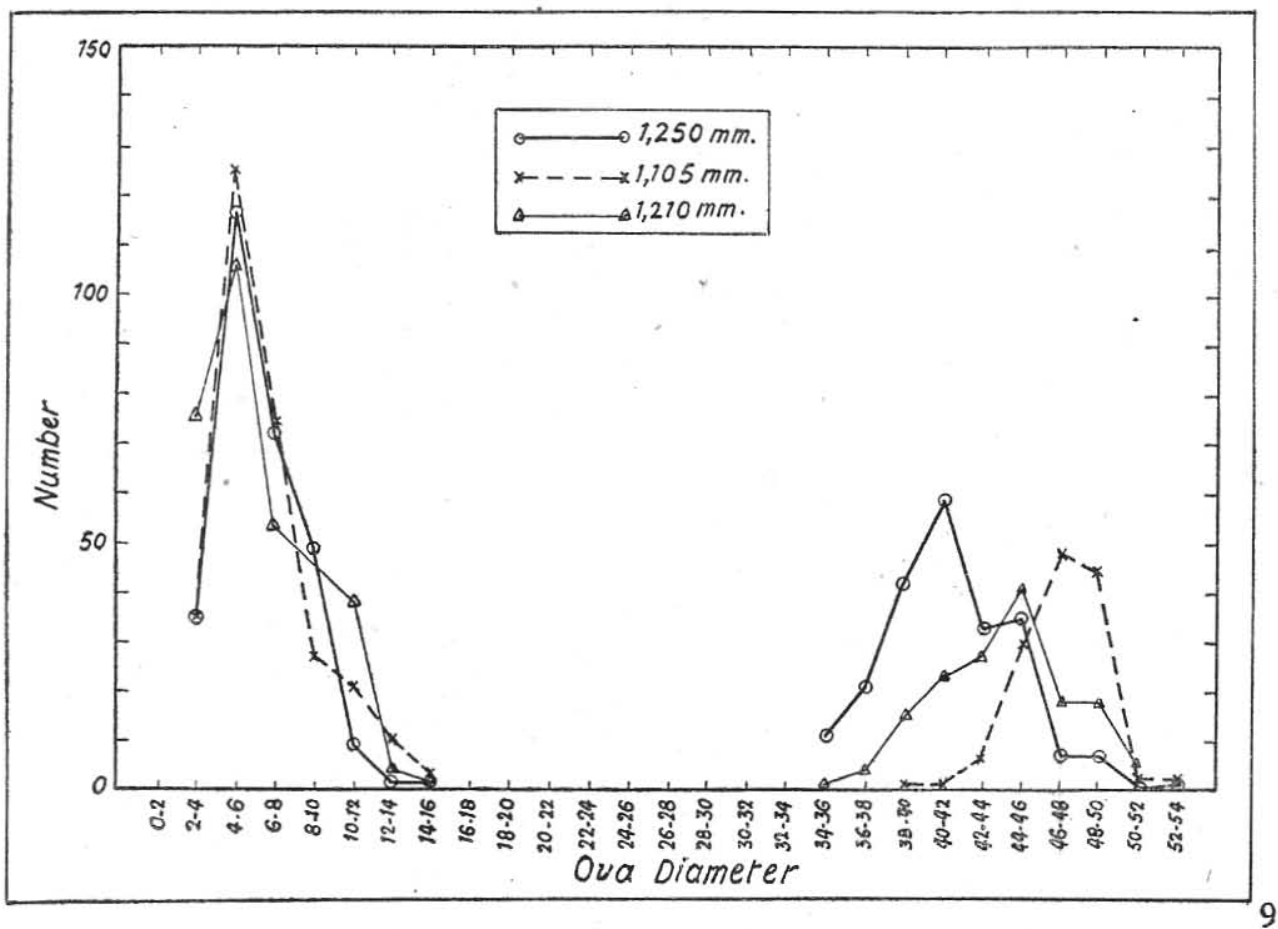

Text-Fig. 9. Ova diameter frequencies in the nearly mature ovaries of three fish.

of mature eggs as may be noticed in the individual curves and the wide range in size seem to indicate a tendency for some sort of fractional spawning within the season. But more material have to be examined and data on the growth rate of the maturing eggs studied over a period of 12 months is necessary for any conclusive evidence. The ova diameter measurements from the spent ovaries of three fish (Text-Fig. 10) also show more or less a single dominant group of immature ova except in the case of the $1,260 \mathrm{~mm}$. fish. But whether the tendency to show up a minor peak corresponding to 10-12 mic. units in this instance is significant or not cannot be explained. Bunag (1951) who studied the spawning period of the fish from ova diameter measurements states that the spawning of Chanos along the Philippine coast is distinctly periodic. However, he seems to believe that the whole batch 
of mature eggs is spawned at one time. In the unfortunate absence of a complete published account of his very interesting studies, further comparison is not possible.

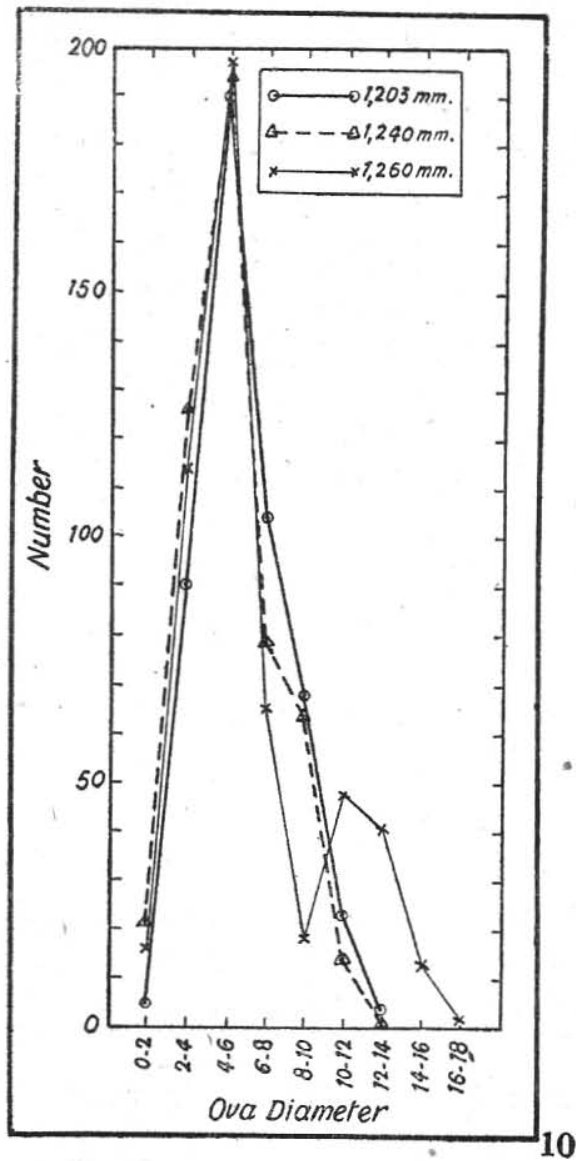

Text-Fig. 10. Ova diameter frequencies in the spent ovaries of three fish.

If the mature ovaries do not suggest the possibility of two spawning seasons in a year for the fish we are confronted with a similar problem as experienced by Bunag (op. cit.). Thus a satisfactory explanation for the occurrence of the fry, though in small numbers, as reported by Panikkar et al. (1952) in the month of November and also by Ganapathy et al. (1950) that the fingerlings are collected near Madras and Pulicat during October to December, becomes difficult. Similarly Delsman (1929) and Schuster (1952) also mention two seasons during which the fry appear along the Indonesian coast where the October-November period is actually the major season for 
fry collections and stocking. Since the two spawning seasons as is suggested by the actual fry collections do not fall at equal intervals in the course of twelve months, the question of the same fish breeding twice a year at unequal intervals may have to be ruled out as this might imply the presence of two types of eggs possessing two different maturation periods (one to be spawned in October-November and another to become mature again with a short period of 4 months by February-March), within the ovaries of the same fish, giving rise to an unequal cycle. This is somewhat unusual. On the other hand, the species as a whole might show two spawning seasons. This will then suggest the existence of another population responsible for giving rise to the subsidiary fry season in which case the necessity for a careful racial study of the species becomes obvious.

Observations through these years have shown that the earliest fry (of about $13 \mathrm{~mm}$. long) appear along the Pamban coast for the first time usually between the second and third week of March although their peak season is from April-May. These fry along with fingerlings continue to occur in the succeeding months and have been collected in fair numbers up to the end of May and in smaller numbers even early in June. According to Delsman as quoted by Schuster (1952) the fry caught along the coast is roughly 2-3 weeks old. Thus we may reasonably assume that the spawning of the fish starts sometime by February and lasts until about the middle of May. The capture of both mature and spent fish within this period supports this. Similarly the wide range in the size of the group of maturing eggs also suggests a somewhat extended period of spawning.

Judging from the reports of Ganapathy et al. (1950) on the peak season of actual fry collection along the South Indian coast, one is inclined to suspect a slight shifting of the intensity of the season from April in the Pamban area to about June in the northern districts of the Coromandel coast. A similar change may be noticed towards the northern regions along the west coast also. If this is significant, it may be interesting to pursue the movements of the fry side by side with the change in factors such as water currents and hydrological conditions along these coastal regions.

\section{BREEDING HABITS}

It is through the classical work of Delsman (1929) that we now have, what seems to be, the only dependable description of the egg and early larvæ of the fish. His material was obtained from plankton in horizontal surface hauls in the Java Sea 15-17 miles from the coast where the sea is 11-22 fathoms (20-40 metres) deep. The only other collection is of Chacko (1950) who 
also obtained the eggs from surface plankton collected around Krusadai Island in the Gulf of Mannar in South India. Since then the present author made a series of regular plankton hauls in these areas both at the surface and also at depths varying up to 6 feet. The collections were made during 1950-55 on months which cover the probable spawning period. Several eggs which conform to the known description of Chanos eggs were obtained in surface hauls while they were absent in the sub-surface collections. These were hatched in the laboratory and reared up to three days. A comparison of these with the corresponding stages given by Delsman showed differences in the manner of arrangement of the muscle fibres, pigmentation, etc. ${ }^{2}$ Frey (1947) states that in Chanos "The females are said to average three to five million eggs, which are thought to be of the demersal type." The reasons for such a statement or the authority on which such a remark is based are not known and would have been interesting especially in view of the fact pointed out by Delsman (1929) that the number of eggs produced by the fish is so great that ".... we may safely draw the conclusion from it that the bandeng is a fish with pelagic eggs, as in fishes with demersal eggs or with some form of parental care not nearly such numbers are found."

Regarding the breeding behaviour of Chanos, the observations of Chacko (1951) which are of great interest have revealed that the fish spawns in selected places in the inshore regions of the coastal waters where there is slight reduction in salinity, which facilitate the drifting of the eggs and larval stages into the backwaters and tidal pools. The spawners which are 3-5 feet in length congregate in small shoals of 50-60, during the nights of the new moon periods in the months of March, April and May. They are said to enter the backwaters if conditions are favourable. The present author, however, has failed to notice these phenomena in areas around Mandapam and the only two occasions when the mature ones were actually caught in the large shore seines were within about 3 miles from the coast.

In this connection, attention may also be drawn to a recent report by $\mathrm{H}$. van $\mathrm{Pel}^{3}$ that Chanos has been found to breed in a salt-water lake in New Caledonia of the Tonga Archipelago. Although this is against the existing belief that the fish do not breed in enclosed waters such a possibility cannot be entirely ruled out. In fish farms we seldom come across a fish with actively

${ }^{2}$ The help rendered by my colleagues Shri S. V. Bapat and Dr. P. Vijayaraghavan, in making plankton collections and a critical study of the newly hatched larvæ, is gratefully acknowledged. Both of them hold the view that these eggs and larvæ belonged to some other clupeoid fish.

3 This report, made in 1956 to the Indo-Pacific Fisheries Council, was made available to me through the kindness of Dr. N. K. Panịkkar, to whom the author's thanks are due, 


\section{Reproduction of Milkfish Chanos chanos (Forskål)}

developing gonad mainly because they are caught, perhaps for reasons of economy, long before this stage sets in. In one specimen of $630 \mathrm{~mm}$. in length captured from the fish farms at Narakkal (Cochin), the ovaries showed distinctly developed lamellæ and the intraovarian eggs corresponded to the early stage described under Stage II. This might indicate that active development of the gonads even in enclosed waters is possible provided the fish are allowed to grow to a sufficient size over a longer period although their actual spawning in such confined space may be questionable. At least in experimental farms it may be interesting to have them reared to a maturing size so that it may throw some light on the physiological needs of the fish associated with sexual maturity. van Pel's observation and also the recent observations by the author (Tampi, 1957) on the food of the fish might be of significance in this line of investigation.

\section{SUMMARY}

1. Some essential morphological and histological features of the very early and nearly mature testes in Chanos are described.

2. Similar accounts of four important stages in the maturation of the ovary and the intraovarian eggs are given.

3. A study of the ova diameter measurements in the limited material indicates that the fish normally spawns only once a year. The type of spawning in the species, egg production, size at maturity and breeding habits are discussed in the light of these observations. The probable lines on which further data may be usefully gathered are also briefly indicated.

\section{LITERATURE CITED}

Adams, W., Montalben, H. R. and Martin, C.

Bretschneider, L. H. and Duyvené de Wit, J. J.

Bunag, D. M.

Chacko, P. I:
"Cultivation of bangos (Chanos) in the Philippines," Philippine J. Sci., 1932, 47 (1), 1-35.

"Sexual endocrinology of non-mammalian vertebrates," Monograph on the Progress of Research in Holland, Amsterdam, 1947, 1-146.

.. "Spawning habits of Chanos chanos (Forskål) based on ova diameter measurements of the developing ovarian eggs," Tech. Paper 165, Indo-Pacific Fish. Coun., Bangkok (Abstract), 1951.

.. "Marine plankton from waters around Krusadai Island," Proc. Indian Acad. Sci., 1950, 31 (3), 162-74.

.. "Survey of Pulicat Lake with special reference to availability of Chanos chanos," Prog. Rep. Madras Rur, Pisc. Scheme, 1950-51, 1-33, 
Chaudhuri, B. L.

Craig-Bennet, A.

De Jong, J. K.

Delsman, H. C.

Franz, V.

Frey, D. G.

\section{P. R. S. TAMPI}

.. "Fauna of Chilka Lake, Fisheries, Part I," Mem. Indian Mus., 1916, 5, 405-39.

.. "The reproductive cycle of the three-spined stickleback, Gasterosteus aculeatus Linn.," Phil. Trans. Roy. Soc., 1931, 219 B, 197-280.

.. "A preliminary investigation of the spawning habits of some fishes of the Java Sea," Treubia, 1939, 17, 307-27.

.. "Fish eggs and larvæ from the Java Sea, Chanos chanos (Forskål)," Ibid., 1929, 11, 281-86.

. " "Die Epiproduktion der Scholle (Pleuronectes platessa)," Wiss. Meeresunt, N.F., 1908, 9 (2), 63-141.

.. “The pond fisheries of Philippines," J. Mar. Res., 1947, $6(3), 247-58$.

Ganapathy, S. V., Chacko, P. I., Srinivasan, R. and Krishnamurthy, B.

"On the acclimatisation, transport and culture of some salt-water fishes in inland waters of the Madras State," Indian Geogr. J., 1950, 25 (2), 1-15.

Hoar, W. S.

.. "Hormones in fishes," Univ. Toronto Biol. Ser., 1951, $59,1-51$.

Matthews, S. A.

. "Seasonal cycle in the gonads of Fundulus," Biol. Bull., 1938, $75(1), 66-74$.

Panikkar, N. K., Tampi, P. R. S. and Viswanathan, $\mathrm{R}$.

"On the fry of the milkfish Chanos chanos (F.), " Curr. Sci., 1952, 21, 18-19.

Prabhu, M. S.

.. "Maturation of intraovarian eggs and spawning periodicities of some fishes," Indian J. Fish., 1956, 3 (1), 59-90.

Schuster, W. H.

.. "Fish culture in the brackish-water ponds of Java," IndoPacific Fish. Counc., Special Publication, 1952, 1, $1-143$.

Sunier, A. J.

.. "Marine fish ponds of Batavia," Treubia, 1922, 2, 159-400.
Tampi, P. R. S.

.. "Some observations on the food of Chanos chanos (Forskål)," Indian J. Fish., 1957 (In press).

\section{Explanation of Plates}

\section{Plate XVII}

FIg. 1. Part of a transverse section of a very early testis from a fish of $690 \mathrm{~mm}$. showing a few lobules of spermatogenic cells, $\times 55$.

FIG. 2. Spermatogenic cells from a $830 \mathrm{~mm}$. fish, $\times 550$.

FIG. 3. Photograph of the mature testes of a $1,140 \mathrm{~mm}$. fish, $\times 1 / 3$.

FIG. 4. Various stages of spermatocytes and fully formed spermatozoa in a spermatic tubule of a mațure testis, $\times 260$. 

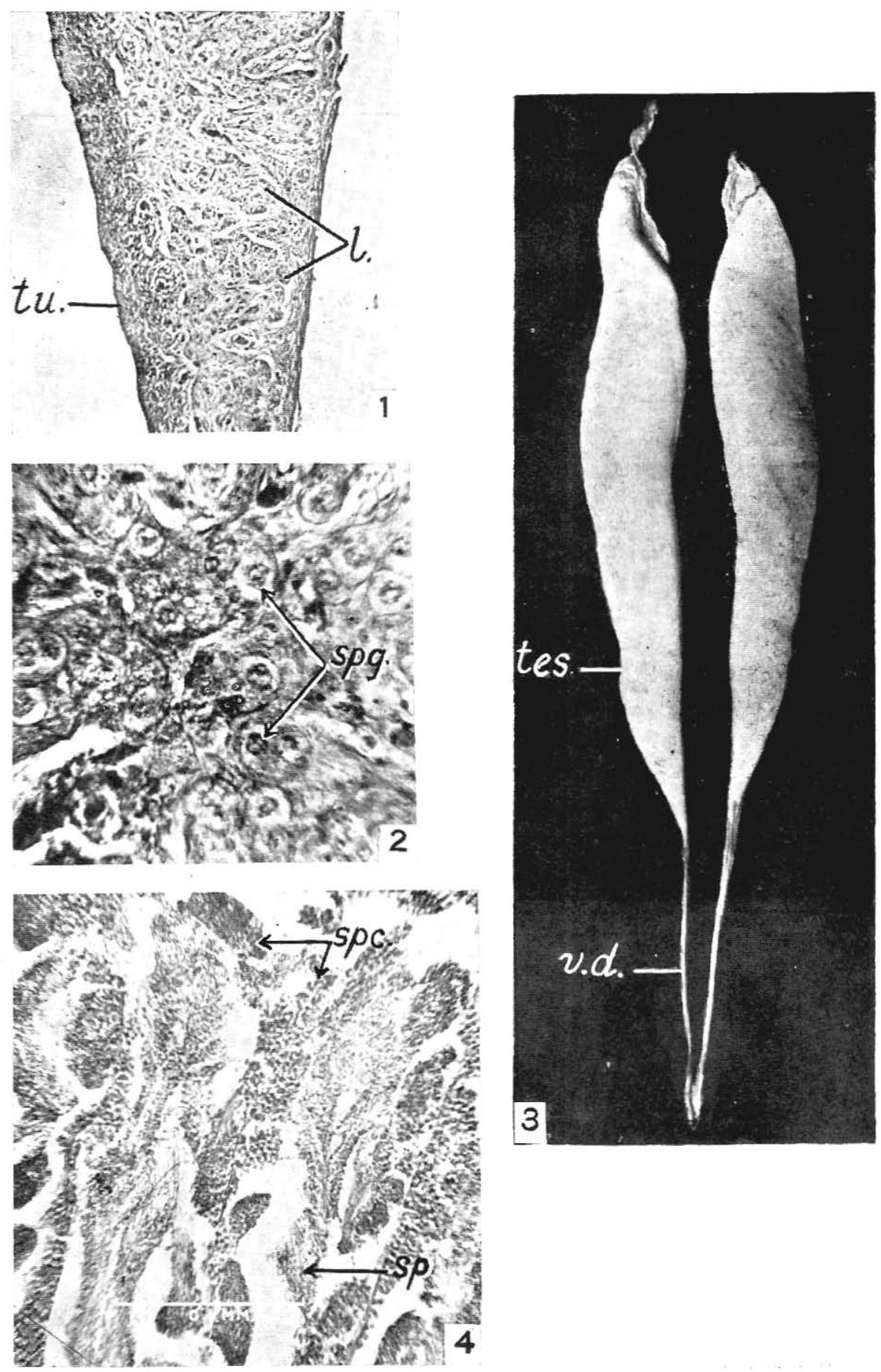

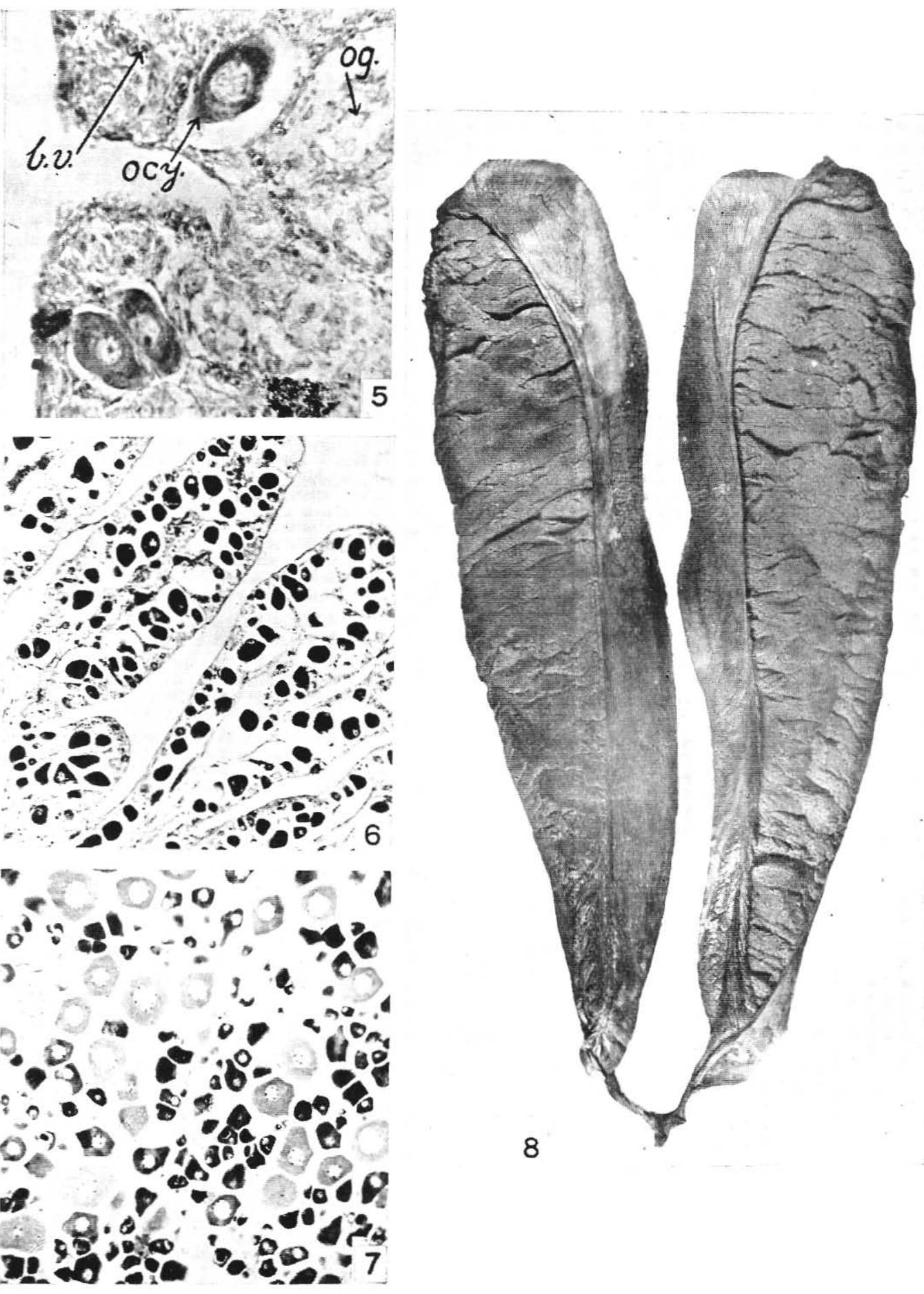

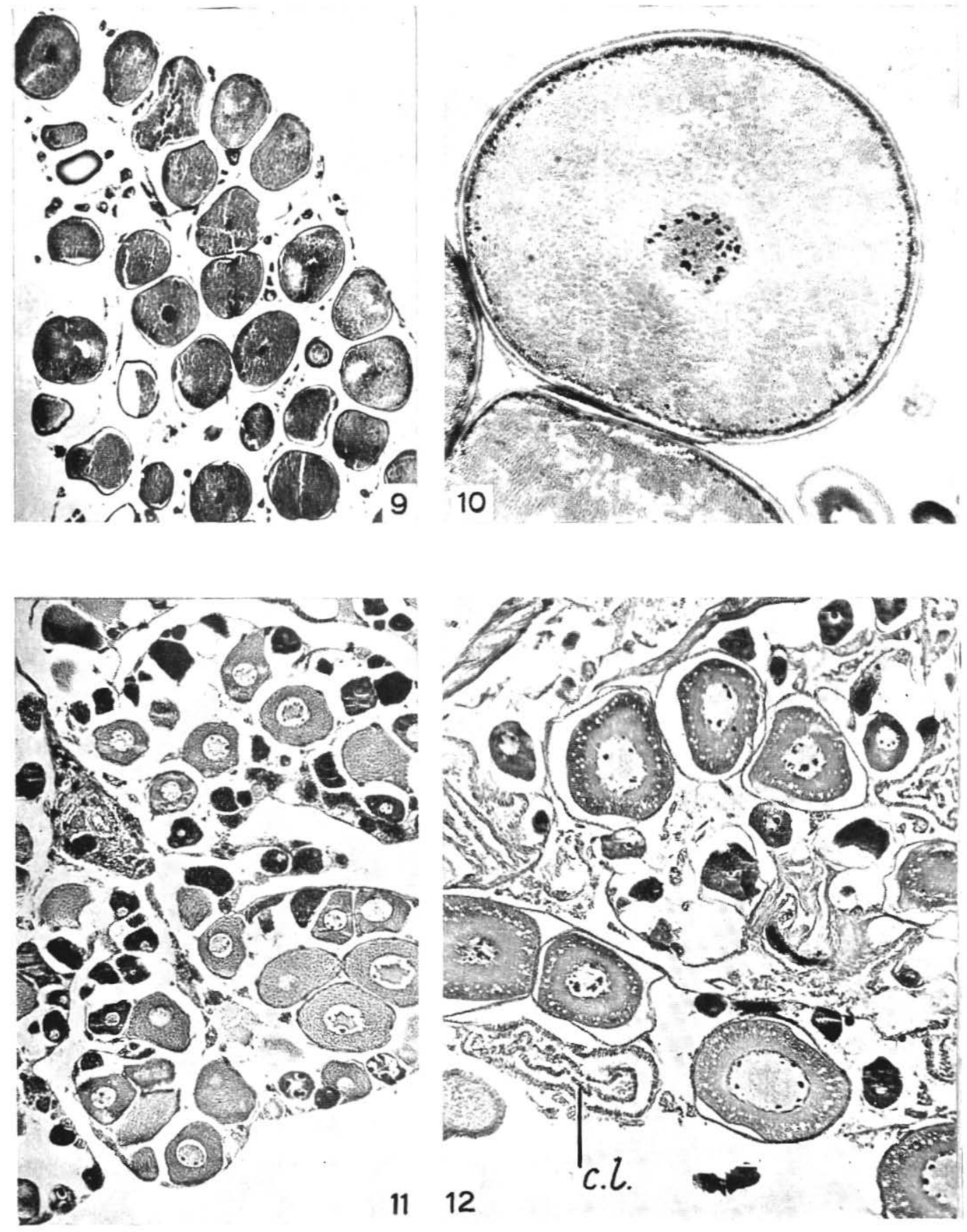


\section{Plate XVIII}

Fig. 5. Oogonial cells and oocytes from the earliest recognisable ovary of a fish of $500 \mathrm{~mm}$. of Stage I, $\times 500$.

FIG. 6. A few ovigerous lamellæ from a $670 \mathrm{~mm}$. fish of early Stage II, $\times 86$.

FIG. 7. Part of the ovary of a $990 \mathrm{~mm}$. fish of Stage II, but more advanced than in Fig. $6, \times 55$.

FIG. 8. Photograph of the mature ovaries from a fish of $1,250 \mathrm{~mm}$. ca. $\times 1 / 3$.

\section{Plate XIX}

FIG. 9. Section of a nearly mature ovary of Stage.III from a $1,210 \mathrm{~mm}$. fish showing a few intraovarian eggs, $\times 17$.

FIG. 10. Section of a nearly mature intraovarian egg, $\times 100$.

FIG. 11. Section of a spent ovary of a fish of $1,240 \mathrm{~mm} ., \times 90$.

FIG. 12. Section of ovary of the fish of $1,260 \mathrm{~mm}$. length. Note the peculiar bodies referred to in the text, $\times 90$.

\section{KeY TO LETTERING}

b.v. Blood vessel.

- c. Cortex.

c.l. "Corpus luteum".

e.m. Egg membrane.

$f$. Marginal fold of ovary.

fu. 'Oviducal funnel'.

l. Lobules of spermatogenic cells.

$m$. Medulla.

mor. Mesorchium.

mov. Mesovarium.

n. Nucleus.

ocy. Oocytes.

og. Oogonial cells. ov. Ovary.

ov.d. Oviduct.

ov.l. Ovigerous lamellæ.

sp. Spermatozoa.

spc. Spermatocytes.

spg. Spermatogonial cells.

sp.d. Spermatic duct.

tes. Testis.

$t u$. Tunica.

v.d. Vas deferens.

$y$. Yolk.

y.g. Yolk granules.

y.v. Yolk vesicles. 